\title{
Role of Instructional Technology in Enhancing
}

\section{Students' Educational Attainment in General Science at Elementary Level in Karak District, Pakistan}

\author{
Qaiser Suleman \\ M.Phil (Education) Scholar, Institute of Education \& Research, Kohat University of Science \\ \& Technology, Khyber Pakhtunkhwa, (Pakistan) \\ Email: Look_for_reality@yahoo.com
}

Dr. Ishtiaq Hussain

Assistant Professor, Institute of Education \& Research, Kohat University of Science \& Technology, Khyber Pakhtunkhwa, (Pakistan)

Email: dr.ishtiaqkust@gmail.com

Dr. M. Naseer-ud-Din

Assistant Professor, Institute of Education \& Research, Kohat University of Science \& Technology, Khyber Pakhtunkhwa, (Pakistan)

Accepted: May 17, $2012 \quad$ Published: January 31, 2013

Doi:10.5296/jsr.v4i1.3190ＵRL: http://dx.doi.org/10.5296/jsr.v4i1.3190

\begin{abstract}
Instructional technology plays a vital role in enhancing instructional process and makes it more interesting, successful and productive (Suleman, et al. 2011a). The purpose of the study was to examine the role of instructional technology in enhancing students' educational attainment in General Science at elementary level in Karak District (Khyber Pakhtunkhwa) Pakistan. All the students at elementary level in Karak District constituted the population of the study. The study was delimited to the students of Government High School Khurram Karak. The study was further delimited to the students of 8th class. Fifty students of class 08 of the same school were selected as sample of the study. Sample students were divided into two groups i.e. control group and experimental group on the basis pre-test. The study was experimental in nature therefore pre-test and post-test technique was used for data collection. Mean, standard deviation and t-test were used for the statistical treatment of the data. After analysis of the data, it was concluded that instructional technology plays a fundamental and crucial role in strengthening students' academic achievement in General Science a elementary level. Based on findings, it is recommended that instructional technologies should be utilized in teaching of General Science at elementary level. Instructional technologies should be provided to each school on priority basis.
\end{abstract}


Keywords: Instructional Technology; Enhancing Students' Educational Attainment; General Science; Elementary Level

\section{Introduction}

Pakistan is a developing country and is continuously struggling for a highly regarded and respectable position in the community of the nations. Pakistan needs a strong foundation of science and technology for the solution of its various problems i.e., problems of food, shelter, energy, health and security, the exploitation of natural resources and the enhancement of agriculture and industrial production. Pakistan has recognized itself as a member of global nuclear power society (Iqbal, 1990). Therefore, it is imperative to pay full attention towards science to achieve these goals ensuring the development of the nation. Soon after the independence, the importance of science education was realized. For this purpose, the first Pakistan Education Conference 1947 set the direction of our education system. In the same conference, Quaid-e-Azam Muhammad Ali Jinnah emphasized upon the importance of science education for our emerging nation and said that "there is no doubt that the future of our nation will really depend upon the education we impart to our children and also the way we bring them up as the future citizens of Pakistan. Education means not only academic education but we need scientific and technological education to our people to strengthen our economic life and to observe that our people adhere to science, trade, commerce and especially well-planned industries. We should remember that we have to compete the world which is moving very fast" (Govt. of Pakistan, 1947).

Science has played a crucial role in facilitating the society and brought revolution in every aspect of society because of rapid increase in scientific knowledge. It is a proved fact that the existence of modern society is the result of scientific inventions and discoveries and that is why it can be called a scientific civilization. Science and technology has played a vital and important role in socio-economic development of a society. It has been universally recognized that the amicable survival of a nation in the 21 st century depends mainly upon the scientific development and scientifically educated society. The foundation on which the structure of the developmental programmes of a nation must be built is its knowledge and expertise in the field of science and technology and its use in agriculture and industry (Rehman and Choudhury, 1998). Science has played a crucial role in facilitating human life and it has affected every aspect of human life and its society. It has changed the life style of human life completely. Therefore, it is imperative to pay full attention towards science. The researchers have to explore the importance of instructional technologies in teaching of science at elementary level. Therefore, the researchers expect that the findings of the study will be beneficial for science teachers to use instructional technologies to make their teaching learning process more effective, interesting, productive and successful. Consequently, competent and skillful individuals will be produced which will bring a constructive revolution in the development of the country.

\section{Review of Related Literature}


Literature review is divided into two sections i.e. Section $-\mathrm{A}$ and Section $-\mathrm{B}$. Section $-\mathrm{A}$ is written about science and its importance. The section $-\mathrm{B}$ is written about instructional technology.

\section{What is Science?}

\section{Section - A}

The word science is derived from a Latin word "Scienttia" which means "to know". Science is a systematized body of knowledge". Science is nothing but organized common science". Science is a heap of truth (Yadav, 1992). Science may be regarded as a field of study which deals with the observations and interpretation of reproducible facts. The word reproducible means the fact that can be repeated or demonstrated to any person. Water normally freezes at $0 \mathrm{oC}$ and boils at $100 \mathrm{oC}$. The electric bulb is lighted when electric current is passed through it. Zinc reacts with sulphuric acid; forming zinc sulphate and hydrogen etc. These facts can be repeated or demonstrated to any person. Hence these facts are science. But the statements like "Babar invaded India in 1526 etc may be true as a statement, but it can not be precisely repeated. Therefore, it will not form the basis for a scientific study, so it is not called science (Khyber Pakhtunkhwa text book board, 2005). According to Shami (2001), science is the systematic study of nature and also the ways how it influences our surroundings and us. It is considered a systematic and organized body of knowledge and systematic process of investigation and interpretation. Rehman (2004) defined science as "any of different intellectual activities related with the physical world and its phenomena and involvement of observation and systematic experimentation". He further defined science as "different discipline or intellectual activities which have certain features in common". According to Gillespie (1992) "Science means both the knowledge contained in such disciplines as astronomy, chemistry, physics, biology, and geology and the activities through which it can be obtained".

\section{Three Main Branches of Science}

There are various branches of science but we will discuss only three branches i.e. physics, chemistry and biology.

\section{Physics}

Physics is that branch of science which deals with the study of properties of mater, energy and their mutual relationship. Different questions arise in our mind when we look at various phenomena of nature around us. We are thinking that why the sun also always rises in the east and sets in the west? How motor cars move? Who does an aeroplane fly in the sky? How sound is produced when we speak? How our image is seen in a mirror? How clouds produce lighting and thunder? How the sun emits light and heat? Why fire is lit by burning of wood in air? We get the answer of these questions in Physics because all phenomena of this kind in universe are related to matter and energy (Suleman, 2006). According to Suleman (2006), subjects studied within the scope of physics are called branches of physics. Due to expanding scope and research in physics, it is usually divided into many branches i.e. Mechanics, Heat and Thermodynamics, Sound, Light, Electromagnetism, Nuclear Physics, 
Biophysics, Solid State Physics, Plasma Physics, Astrophysics, Elementary Particles Physics, Geophysics, Health Physics

\section{Chemistry}

Chemistry is derived from the word "Keem" which is the old name of Egypt and probably given to it due to back color of the Egyptian soil. The art of khemia flourished in the early Egyptian and Greek civilizations. The word khemia then became Al-Kimiya in the Arabic and then it became alchemy in English language. "Chemistry is the branch of science which deals with the matter, properties, composition, structure and chemical changes in matter and the laws and principles, which govern these changes". The basic purpose of chemistry is to know about the matter, its properties and the chemical changes which take place in it. In this regard, man continued learning about many things in the universe. These natural and gradual findings and discoveries added much to the knowledge of chemistry. For example, when man burnt the wood for the first time to produce fire, he discovered combustion. From this action, man also learnt that wood can burn but stone can not. Man not only learnt to use silver, copper and gold during the evolutionary stages of the early human civilization but also discovered methods of extraction of iron, mercury and tin from their ores. Glass was also made in that period. It became possible to obtain medicines, oils and dyeing materials from the plants. It is true that man was ignorant of the principles of science but he did have some practical experience of some metals and chemical compounds. Therefore, it can rightly be said that the beginning of the science of chemistry is the beginning of the human civilization (NWFP, 2005). Chemistry is a comprehensive and broad subject that is why it is not possible to cover it in a single subject. Therefore, it has been divided into many branches i.e. Physical Chemistry, Inorganic Chemistry, Organic Chemistry, Analytical Chemistry, Biochemistry, Nuclear Chemistry, Industrial Chemistry, Environmental Chemistry etc. (NWFP, 2005).

\section{Biology}

Biology is the science of life. It is the scientific study of various aspects of living things. The word has been derived from two Greek words, bio means life and logos means study, knowledge or thought. We know that things on the earth are either living or non-living. There are various types of organisms around us showing great variations in size, habit, appearance and mode of life. There are three main groups of biology i.e. Botany, Zoology and Micro Biology. Botany is study of plants and zoology is study of animals. Microbiology deals with the study of microorganisms, such as viruses, bacteria, fungi etc which can only be seen under the microscope. An organism is studies in different way. To understand the life aspects of an organism in a good way, biology is divided into a number of branches i.e. Morphology, Histology, Cell Biology, Physiology, Ecology, Taxonomy, Genetics, Embryology, Paleontology, Biochemistry, Biotechnology (NWFP, 2005a).

\section{Role of Science in Daily Life}

Science has played a crucial role in facilitating human life. It has affected every aspect of human life and its society. Below some importance of science are explained which are as under: 


\section{Role of Physics in Society}

Physics plays an important and crucial role in our daily life. Physics has changed life style of man completely; there are many achievements of physics. Now-a-days through satellite communication, we can watch any event occurring anywhere in the world. Now a man can travel at the speed of sound with help of aeroplanes, a wonderful invention of science. The aeroplanes and other means of transport have shortened the distances and now men do not live in isolation. Through the knowledge of physics, man has succeeded in landing on moon. We can dive deeper into the ocean bed. Energy plays an important role in the development of the country. We are able to utilize the energy stored in coal and petroleum because of physics. Electricity is our most important requirement. At home or in the office, the light produced by the electric bulbs is also the blessing of physics. Through electricity we can enjoy radio, computer, television, wireless, telephone and other automatic machines. These technologies continually facilitating our lives are the fruits of the physics. We can use food stuff for many weeks due to the invention of deep freezers which preserve food from spoilage. The electronic microscope has disclosed many hidden realities. X-rays, ultrasonic, LASER, ECG, EEG, fiber optics and many other such tools have brought revolutionary changes in the diagnostic techniques of medical science.

\section{Role of Chemistry in Society}

The importance of chemistry has been increased to a very high degree due to its application in all aspects of man's life. It has played a very important role in our life. It has contributed a lot towards the welfare and well being of mankind in the form of food, clothing, shelter and medical treatment and in providing entertainment facilities. A variety of chemical fertilizers are being prepared in thousand of industries daily. Mass production of commodities is amazing which save people from starvation. Using pesticides is protecting crops. Food processing factories are working day and night for preparing refined food. The production of a variety of artificial fibers has brought a revolution in our clothing. We enjoy colorful and fine dresses for all seasons due to chemistry. Cement, iron, brick, glass etc, used in the construction of our houses are the result of our knowledge of chemistry. The attractive and colorful paints available in the markets are the products of chemistry, which are used for making houses beautiful. Polyester fiber, fiber glass, different types of plastic, multi-colour glasses, pretty glass crockery, tiles, ceramics, stainless steel and alloys of different metals are all amazing products of chemistry. Petroleum and thousands of petrochemicals have provided countless facilities to us for our daily life. The benefits of chemistry are so numerous and varied in nature that practically no aspect of human life has remained unaffected. The modern life has got another aspect as well. The smoke emitting from chimneys of chemical industries and increasing number of automobiles produce pollutant impossible even to breathe in some industrial areas. This polluted air has adverse effects on human health. It is our responsibility to reduce the level of this pollution using our knowledge of chemistry. Chemists have prepared high explosives, which are used for the defense of a country. Poisonous, tear, fire producers and fire extinguishers, gas masks, heavy guns, tanks, airplanes etc all play a very important role in war and are developed by the chemistry. These weapons are mostly made of 
metals, which are obtained by the chemical process. Atomic bombs and hydrogen bombs are also the gifts of chemistry due to fear of its use, the nations enjoy peace.

\section{Role of Biology in Society}

Being the science of life, biology is directly related to our daily life. The basic use of all scientific information is to improve the quality of our lives. Man depends either directly or indirectly for his needs on other living organisms. In short the biological study enabled us to improve our own life and lives of the other organisms to get maximum benefits from them. All living organisms need food and without it they cannot survive. The human population increases day by day which has definitely caused food shortage. It is through the advancement in biology that man has been able to produce food in greater quantities. New varieties of wheat, rice, sugarcane, maize and cotton have been introduced which are of good quality and with yield. Man has overcome the problem of food shortage due to the advancement in the different fields of biology.

Good health is the basic necessity of life but diseases have been a part of men, animals and plants lives. The development of new drugs and vaccines as a result of biological researches has been very helpful not only to man but also to animals and plants. Vaccination has greatly reduced the mortality rate in child by control over diseases like, small pox, polio, tetanus and diphtheria. The discovery of new antibiotic drugs has greatly controlled infectious diseases like cholera, typhoid, pneumonia, tuberculosis and plague. Many kinds of pesticides save food crops from diseases by eliminating harmful pests. The rapid rate of human population growth, the increasing number of factories and ever increasing number of automobiles has become greatest sources of land, water, and air pollution. Environmental pollution is not only a threat to the life of man but also to plants and animals that live around us including aquatic and wild life. Deforestation an over grazing has greatly affected our ecosystem. It is through biological research that biologists are tying to find out the means and ways to overcome the harmful effects of pollutants of environment. Genetic engineering is artificial alteration in the hereditary material of an organism. Useful genes are inserted into bacteria etc to obtain beneficial result by the techniques of genetic engineering or biotechnology. Genetic engineering is used to increase plant and animal food production. It is also employed to diagnose diseases, improve medical cure and production of vaccines and other useful drugs.

\section{What is Instructional Technology?}

\section{Section - B}

Educational technology is often used interchangeable with the instructional technology. However, there is considerable difference between these two terms. Educational technology is broad and comprehensive subject than instructional technology. Instructional technology is the part of educational technology. Seels and Richey (1994) explained that the term educational technology is broader than instructional technology because educational deals with ,all aspects of education ${ }^{\text {ee }}$ while the term instructional is only restricted to teaching and learning problems. According to Venkataiah (1996), although the term instructional 
technology is often used same with educational technology, it presents certain refinements that are not found in meanings of educational technology (Suleman, et al. 2011b). Instructional technology has been defined into different ways. Heinich et al. (1993) defines instructional technology as "the application of scientific knowledge relating human learning to the practical tasks of teaching-learning process". Seels and Richey (1994) defines instructional technology as "the theory and practice of design, development, utilization, management and evaluation of processes and resources for learning. According to Armsey and Dahl (1997), instructional technology is comprised of those things, devices, tools and materials, which are utilized in the instructional process. Sharma \& Sharma (2006) explains that instructional technology is the application of sociological, psychological and scientific principles and knowledge in teaching learning process to achieve learning objectives. It is the system and net work of devices, instruments, methods and techniques used to attain certain defined set of learning objectives. Wiken (2005) explained that the use of technology in the instructional process enhances motivation, engagement and interest when students use multimedia programmes and software designed to develop skills sand knowledge. The application of audio and video technologies brings content to life and simulates learning.

Instructional technology plays an important role in understanding complex and difficult things relating to instructional process and it saves the teacher time. Kadzera (2006) writes that "by the use of instructional technology, the teacher can easily explain those complex and difficult concepts, which are difficult to explain in words or orally. When students see the instructional materials, its mechanism and its functions, teachers do not need explanation and students easily understand the things taught by teachers". According to the Malawi Ministry of Education (1995), by the use of instructional technologies, the teachers are able to explain complicated and difficult concepts that are difficult to explain in words. When the students observe the things, its mechanism and its functions, they easily understand what the teacher is saying and thus teachers are saved the hard explanation. Gillani (2006) found that during the treatment, the students of the experimental group were found to be more attentive because the concepts were explained with the help of instructional technology and with concrete examples, played a crucial and remarkable role in teaching learning process. Suleman et all (2011a) conducted a research study to explore the usefulness of technology in teaching chemistry at secondary school level in Khyber Pakhtunkhwa. They arrived at the conclusions that educational technologies play an effective role in teaching of chemistry. The students of experimental group showed excellent results as compared to the students of control group. Furthermore, they also found that high and low achievers of the experimental group also showed excellent results as compared to the low and high achievers of the control group. Educational technologies increased the interest of students. It increased the motivational level of the students. It also increased the attentiveness of the students. It also found effective in the clarification of difficult scientific concepts.

\section{Characteristics of Instructional Technology}

According to Sharma and Sharma (2006), important characteristics of the instructional technology are:

- It helps in attaining cognitive objectives effectively. 
- By the use instructional technology, the right responses of the students are confirmed for providing the reinforcement continuously.

- It provides opportunities to students to learn according to his own speed and needs.

- By the use of instructional technologies, psychological learning theories and principles can be incorporated.

- It assists in creating the learning external conditions, contiguity practice and reinforcement.

- By using instructional technology, instruction theories can be developed in learning process.

- It can be utilized in storage of competent teachers.

- It provides the deep insight into the context structure and sequence of its elements.

\section{Statement of the Problem}

The present study was designed to explore the effectiveness of instructional technologies in strengthening academic achievement of students in subject of General science at elementary level. Therefore, the statement of the problem was entitled as "Role of Instructional Technology in Enhancing Students' Educational Attainment in General Science at Elementary Level in Karak District, Pakistan”.

\section{Objectives of the Study}

The objectives of the study were:

1. to find out the effect of instructional technology on the academic attainment of students at elementary level

2. to determine whether teaching through instructional technology is more useful than the traditional method of teaching science at elementary level

3. to investigate whether the students can retain the learning for a longer time when they taught through instructional technology

\section{Hypotheses of the Study}

To achieve the above mentioned objectives of the research study, the following null hypotheses were developed:

1. There is no significant different between the performance of control and experimental groups on pre-test.

2. There is no significant difference between the performance of the control and experimental groups on post-test.

3. There is no significant difference between the performance of control and experimental groups on retention test.

\section{Research Methodology}

\section{Population of the Study}

All the students studying at elementary level in Karak District (Khyber Pakhtunkhwa) 
Pakistan constituted the population of the study.

\section{Sample and Sampling Technique}

Fifty students of class 08 of the Govt. High school Khurram (Karak) were selected as sample through simple random sampling technique. Sample students were divided into two groups i.e. control group and experimental group by equating them on their previous knowledge in subject of science as determined through a pre-test.

\section{Delimitations of the Study}

The study was delimited to the students of Government High School Khurram (Karak). The study was further delimited to the students of 08th class. The study was also delimited to the following six chapters in subject of General science:

\begin{tabular}{llll}
\hline Units & Title of the Units & Units & Title of the Units \\
\hline $\mathbf{0 1}$ & Vertebrates & $\mathbf{0 4}$ & Carbon and Its Compounds \\
$\mathbf{0 2}$ & Laws of Chemical Combination & $\mathbf{0 5}$ & Acids, Bases and Salts \\
$\mathbf{0 3}$ & Chemical Bond & $\mathbf{0 6}$ & Temperature \& Thermal Expansion \\
\hline
\end{tabular}

\section{Research Design}

For experimental study, normally "The pre-test-post-test Equivalent Groups Design" is used. Therefore, the researchers decided to use this research design. According to this design, sample students are adjusted in experimental and control groups on the basis of pre-test. This research design is symbolized as follows (Suleman et al. 2011a):

$\begin{array}{llllll}\mathbf{R} & \mathbf{E} & = & \mathbf{O 1} & \mathbf{T} & \mathbf{O 2} \\ \mathbf{R} & \mathbf{C} & = & \mathbf{O 3} & & \mathbf{O 4}\end{array}$

Where

$$
\begin{array}{ll}
\mathrm{R}=\text { Randomly selected } & \mathrm{E}=\text { Experimental Group } \\
\mathrm{C}=\text { Control Group } & \mathrm{O}=\text { Observation or Mearsurement } \\
\mathrm{T}=\text { The experimental treatment } &
\end{array}
$$

\section{Research Instrumentation}

To compare the performance of the both groups i.e. control group and experimental group, a question paper was prepared in the selected six units of General Science and then distributed among the students of both groups before the treatment. Likewise, another paper was developed and distributed among the sample subjects of both groups after experiment. These two question papers were used as data collection source.

\section{Appointment of Science Teachers for Experimentation}

It was an experimental study, hence two science teachers having equal academic and professional qualifications and teaching experience were selected. Both teachers have been 


\section{Macrothink}

serving in elementary and secondary education department in Khyber Pakhtunkhwa since 2004. Their qualifications were B.Sc and B.Ed.

\section{Training of Teacher in Using Instructional Technologies}

As researches studies have revealed that majority of the teachers are not trained for effective utilization of technologies i.e. computer, multimedia, overhead projector, DVD Player etc (Suleman, 2011; Suleman et al. 2011b). Therefore, it was imperative to train the science teacher appointed to experimental group in the use of these electronic devices. Therefore, the same science teacher was given one week training for the effective use of technologies in teaching learning process.

\section{Data Collection}

In order to collect data, the researchers along with other two science teachers administered a pre-test and then a post-test to the both groups. For this purpose, two question papers were developed covering the six units of the General science. In this way data was collected.

\section{Data Analysis}

In order to analyze the data statistically, raw scores were tabulated obtained from both test i.e., pre-test and post-test. Statistical tools i.e., means, standard deviation, and differences of means were calculated for each group. Significance of difference between the mean scores of both the experimental and control groups on the variable of pre-test and post test scores was tested at 0.05 level by using t-test. For this purpose, the following statistical formulae were used:

\section{Mean Formula}

The following formula was applied to calculate mean of the data:

Mean of the data was calculated by the following formula:

$$
\text { Mean }=\bar{X}=\frac{\sum f x}{\sum f}
$$

Where

$$
\bar{X}=\text { Mean } \quad \mathrm{X}=\text { data } \quad \mathrm{f}=\text { Frequencies }
$$

\section{Standard Deviation Formula}

Standard Deviation of the data was calculated by the following formula:

$$
\mathrm{SD}=\sqrt{\frac{\sum X^{2}-\frac{\left(\sum X\right)^{2}}{N}}{N-1}}
$$

Where $\mathrm{N}$ stands for Total no of frequencies/respondents 


\section{T-Test Formula}

For t-test the following formula was used to find out the value of $t$ :

$$
\mathbf{t}=\frac{\overline{X_{1}}-\overline{X_{2}}}{\sqrt{\left(\frac{S S_{1}+S S_{2}}{n_{1}+n_{2}-2}\right)\left(\frac{1}{n_{1}}+\frac{1}{n_{2}}\right)}}
$$

Where

$$
\mathrm{SS}=\sum X^{2}-\frac{\left(\sum X\right)^{2}}{N}
$$

\section{Analysis and Interpretation of Data}

The study was conducted to examine the role of instructional technologies in enhancing students' educational attainment in subject of General Science at elementary level. Sample students were divided into two groups i.e., control group and experimental group on the basis of pre-test. Both the groups were taught through usual methods by two science teachers of the same qualifications and teaching experience. During the treatment, instructional technologies i.e. computers, multimedia, overhead projectors, and DVD player were used for the experimental group only. This experiment was continued for eight weeks. After the completion of the treatment, the researchers administered a post-test immediately in order to explore whether students of experimental group have learnt well as compared to the students of control group or not. For this purpose the researchers made question paper covering the six units of General Science taught during treatment for both groups. After two weeks, the researchers administered the same post-test for a second time with minor change in the sequences of the questions as a retention test to the students of both groups. In this way data was collected and compared. The detail of the analysis is given as under:

Ho 1: There is no significant different between the performance of control and experimental groups on pre-test.

Table 1: Significance of difference between the mean scores on pre-test of control and experimental groups

\begin{tabular}{lcccccc}
\hline Category & $\mathbf{N}$ & Mean & SD & SED. & t-value & p-value \\
\hline Experimental Group & 25 & 53.64 & 2.68 & & & \\
Control Group & 25 & 53.60 & 2.78 & & $\mathbf{0 . 0 5 2}$ & .959 \\
\hline Non-Significant & df $=\mathbf{4 8}$ & $\mathbf{( p > 0 . 0 5 )}$ & & table value of $t$ at $\mathbf{0 . 0 5}=\mathbf{2 . 0 1}$
\end{tabular}

Table 01 illustrates that the calculated value of $t$ was found to be 0.052 which is statistically not significant because it is less than the table value of $t$ at 0.05 level. Hence the null hypothesis that "There is no significant different between the performance of control and experimental groups on pre-test" is accepted. It explicitly indicates that the students of both groups performed equally on pre-test. 
Ho 2: There is no significant difference between the performance of the control and experimental groups on post-test.

Table 2: $\quad$ Significance of difference between the mean scores on post-test of control group and experimental group

\begin{tabular}{lcccccc}
\hline Category & N & Mean & SD & SED. & t-value & p-value \\
\hline Experimental Group & 25 & 91.24 & 1.24 & & & \\
Control Group & 25 & 67.60 & 2.14 & & & \\
\hline
\end{tabular}

Significant $\quad(p<0.05) \quad$ df $=48 \quad$ table value of $t$ at $0.05=2.01$

Table 2 indicates that the calculated value of $t$ was found to be 47.79 which is statistically significant because $(p<0.05)$ it is greater than the table value of $t$ at 0.05 level. Hence the null hypothesis that "There is no significant different between the performance of control and experimental groups on post-test" is rejected. It unambiguously depicts that students of experimental group showed significantly excellent performance as compared to the control group on post-test.

Ho 3: There is no significant difference between the performance of control and experimental groups on retention test.

Table 3: Significance of difference between the mean scores on retention test of control and experimental groups

\begin{tabular}{lcccccc}
\hline Category & N & Mean & SD & SED. & t-value & p-value \\
\hline Experimental Group & 25 & 87.88 & 1.45 & & & \\
Control Group & 25 & 63.56 & 2.40 & & & \\
\hline
\end{tabular}

Significant $\quad(p<0.05) \quad$ df $=48$

table value of $\mathrm{t}$ at $0.05=\mathbf{2 . 0 1}$

Table 3 illustrates that the calculated value of $\mathrm{t}$ was found to be 43.37 which is statistically significant $(p<0.05)$ because it is greater than the table value of $t$ at 0.05 level. Hence the null hypothesis that "There is no significant different between the performance of control and experimental groups on retention test" is rejected. It showed that the students of experimental group showed significantly excellent performance as compared to the students of control group on retention test.

\section{Discussions}

The study was conducted to examine the effectiveness of instructional technologies in enhancing students' educational attainment in subject of General Science at elementary level in district Karak. In order to divide the sample into two groups i.e. control group and experimental group, a pre-test was administered. On the basis of the same test sample was 
divided into control and experimental groups. Both the groups were taught through usual methods by two science teachers of the same qualifications and teaching experience. During the treatment, instructional technologies i.e. computers, multimedia, overhead projectors, and DVD player were used for the experimental group only. This experiment was continued for eight weeks. After the completion of the treatment, the researchers administered a post-test immediately in order to explore whether students of experimental group have learnt well as compared to the students of control group or not. For this purpose the researchers made question paper covering the six units of General Science taught during treatment for both groups. After two weeks, the researchers administered the same post-test for a second time with minor change in the sequences of the questions as a retention test to the students of both groups.

Table 1 indicates that there is no significant difference between the mean scores of experimental and control group on pre-test. The calculated t-value was found to be 0.200 which is non-significant $(\mathrm{p}>0.05)$ at 0.05 level of confidence. Therefore it unambiguously shows that there is no significant difference between the performance of students of experimental (mean=53.64, $\mathrm{SD}=2.68$ ) and control group (mean=53.60, $\mathrm{SD}=2.78$ ) on pre-test. Thus it can be concluded that performance of students of experimental and control group was same on pre-test. Therefore, the null hypothesis "there is no significant difference between the performance of experimental and control group on pre-test" is accepted.

Table 2 shows significant difference between the mean scores of experimental and control group on post-test. The calculated t-value was found to be 26.48 which is significant $(p<0.05)$ at 0.05 level of confidence. Therefore it obviously indicates that there is significant difference between the performance of students of experimental and control group on post-test. Hence the result reveals that the students of experimental group (mean= 91.24, $\mathrm{SD}=1.24$ ) showed better performance as compared to the students of control group (mean=67.60, SD=2.14). Therefore, the null hypothesis "there is no significant difference between the performance of experimental and control group on post-test" is rejected.

Table 3 depicts significant difference between the mean scores of experimental and control group on retention test. The calculated t-value was found to be 21.88 which is significant $(\mathrm{p}<0.05)$ at 0.05 level of confidence. Thus it plainly indicates that there is significant difference between the performance of students of experimental and control group on retention test. Hence the result reveals that the students of experimental group (mean= 87.88, $\mathrm{SD}=1.45$ ) showed better performance as compared to the students of control group (mean=63.56, SD=2.40). Thus the null hypothesis "there is no significant difference between the performance of experimental and control group on retention test" is rejected. The results of the study also revealed that students of experimental group were found more interested, attentive and motivated during the treatment. On the other hand, students of control group were found passive, tired and frustrated. 


\section{Macrothink}

\section{Conclusions}

The students of experimental group showed unexpected better performance than the students of control group in subject of General Science. The application of instructional technology i.e. computers, multimedia, overhead projectors, DVD player etc in teaching of General Science was found to be more effective and useful. Instructional technologies were found very effective in increasing the motivational level of the students. The students of the experimental group were found to be more attentive and stimulated. Instructional technologies were also proved more helpful and effective in the clarification of students' concepts. Teaching of General Science with instructional technology was found more effective and successful as compared to traditional teaching regarding retention of learning. Furthermore, the students of experimental group showed significantly excellent performance as compared to the students of control group on retention test.

\section{Concluding Remarks}

In nutshell, instructional technology plays a crucial role in strengthening and improving students' academic attainment in subject of General Science at elementary level. It increases the motivational and achievement level of the students. It is very useful in clarifying difficult scientific concepts.

\section{Recommendations}

Keeping in view the above conclusions, the researchers make some recommendations which are described as under:

1. Instructional technology plays a vital role in teaching of science and helps in clarifying difficult concepts of science. In addition, the use of instructional technology proved to have significant positive effect on the achievement of students in subject of science therefore, it is strongly recommended that all the science teachers should utilize technology in their teaching learning process.

2. Poor availability of instructional technology i.e. computers, multimedia, DVD players, educational televisions, radios, VCRs, overhead projectors etc in our institutions is the main problem. Most of the schools lack of these technologies. Therefore it is strongly recommended that these technologies should be provided to all schools on the emergency basis. In addition, other technologies i.e. models, pictures, maps, flip charts, charts, film strips, educational software, flash cards etc should also be provided to all schools.

3. A special training programme should be introduced for the effective use of technologies. All the in-service teachers should be provided training opportunities to make them competent in using these technologies.

4. A compulsory subject regarding the preparation or utilization of instructional technologies should be introduced in teacher training programmes so that the student teachers may be trained in using technologies.

5. As we know that in Pakistan, load shedding of electricity is the main problem in using technology therefore alternate power supply should be ensured to each school for the 
effective integration of technologies. Therefore, it is strongly recommended that power generators should be given to each school on priority basis.

6. Physical and technical infrastructure should be designed in such a way that technologies may be used effectively.

7. A special supervisory staff should be recruited by the government to examine the use of technologies in the schools by teachers.

8. Special budget should be provided to schools by the government to purchase instructional technologies.

\section{References}

Armsey, J. W., \& Dahl, N. C. (1973). An Inquiry into the Uses of Instructional Technology. A Ford Foundation Report. p.VIII

Braham, M. (1977). The Grounding of the Technologies. In R. Budgett \& J. Leedham, J. (Eds.), Aspects of Educational Technology VII, London: Pitman Publishing, pp. 45-56

Collette, A. \& Chiappetta, I. (1989). Science Instructions in the Middle and Secondary Schools. 2nd ed. Merrill Publishing Company, Columbus. USA.

Gillani, S. N. (2005). Effectiveness of Instructional Technology in Teaching Biology to Secondary School Students. Ph.D Thesis, University Institute of Education \& Research, University of Arid Agriculture Rawalpindi, Pakistan. pp.100, 110-102.

Gillispie, C. C. (1992). Science, In: Morris, C., (ed.) Academic press dictionary of science and technology, San Diego: Academic Press, p. 1926.

Government of Pakistan, (1947). Proceedings of the first Pakistan Education Conference. Ministry of Interior (Education Division). Karachi, Pakistan. pp. 1-19

Heinich, R., Molenda, M., \& Russell, J. D. (1993). Instructional Media and the New Technologies of Instruction. New York: Macmillan. p.16

Iqbal, M. Z. (1990). Science Education in Pakistan. A New Look In: M. M. Zafar, (ed.), Science Technology and Development Pakistan Council for Science and Technology, Islamabad, Paksitan.pp.1-10

Kadzera, C. M. (2006). Use of Instructional Technologies in Teacher Training Colleges in Malawi. Ph.D Thesis. Virginia Polytechnic Institutes and State University.

Kumar, K. L. (2006). Educational Technology. New Age international (P) Limited, Publishers New Delhi. p. 2

Ministry of Education. (1995). Resource notes for new primary school teachers. Extracted from a training manual for UNICEF: Child survival and development project. Lilongwe, Malawi. N.W.F.P. (2005). Chemistry for 9th Class. NWFP Textbooks Board Peshawar. pp. 1-6

N.W.F.P. (2005a). Biology for 9th Class. NWFP Textbooks Board Peshawar.

Yadav, M. S. (1992). Teaching of Science. Anmol Publications. New Delhi, India. Pp.1-9

Seels, B. B., \& Richey, R. C. (1994). Instructional Technology: The definition and Domains of the field. Association for Educational Communications and Technology: Washington, D.C. p.1, 4 